\title{
De Realibus ad Realiora: a violência em Rubem
}

\section{Fonseca}

\author{
Deivis Jhones Garlet ${ }^{1}$ \\ Laís Ismael Freitas ${ }^{2}$
}

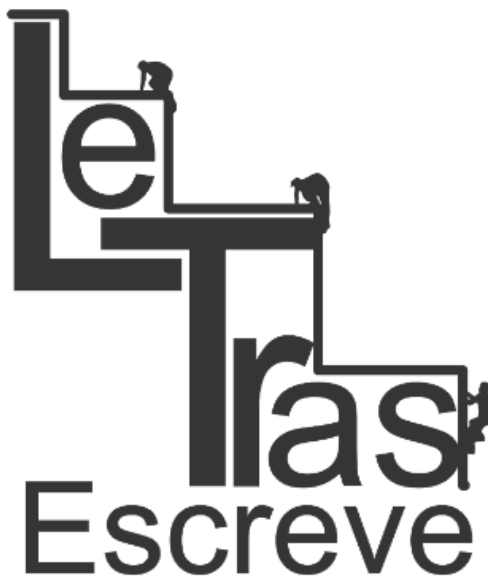

(ISSN 2238-8060)
Resumo: Argumentaremos, neste trabalho, que uma forma narrativa de matiz realista ainda pode ser profícua na expressão de conteúdos traumáticos, a exemplo da violência. Nesse sentido, entendemos que uma forma de narrar desprovida de significativo experimentalismo, como os contos Feliz ano novo e Passeio noturno (Partes 1 e 2), de Rubem Fonseca, pode desvelar uma essência de realibus ad realiora, do real ao mais real. Sendo tal argumento legítimo, a violência na obra do escritor aponta para uma posição axiológica de crítica social.

Palavras-chave: Violência; Rubem Fonseca; Axiologia.

ABSTRACT: we argue in this paper that a realistic hue narrative form can still be profitable in the expression of traumatic content, such violence. In this sense, we believe that a way of narrating devoid of significant experimentalism, as the tales Happy New Year and Night Tour (Parts 1 and 2 ), by Rubem Fonseca, can unveil the de realibus ad realiora, the most real real. Being such a legitimate argument, violence in the writer's work points to an axiological position of social criticism.

Keywords: Violence; Rubem Fonseca; Axiology.

Em recentes trabalhos acerca da literatura brasileira contemporânea, Ginzburg (2001 e 2012) salienta a emergência e a necessidade de novas formas de representação no pós-Segunda Guerra. Ancorado em teses de Adorno, Benjamin e lan Watt, sobremodo quanto à categoria narrativa do narrador, o crítico sustenta que a violência, o trauma e demais situações extremas não poderiam mais ser narrados pelos métodos da estética realista (dos séculos XVIII e XIX), exigindo, então, novas formas de expressão para se constituírem. Apresenta como exemplos de uma renovação da literatura brasileira autores como Raduan Nassar e Renato Tapajós, entre outros. Argumentaremos, contrário senso, em defesa

\footnotetext{
${ }^{1}$ Doutorando em Letras, Estudos Literários, na UFSM; Mestre em Letras, Estudos Literários, UFSM; Especialista em Pensamento Político Brasileiro, UFSM; Graduado em História, UFSM. E-mail: deivisjh@hotmail.com

${ }^{2}$ Graduanda em Psicologia, FISMA. E-mail: laisfreitaspsicologia@hotmail.com
}

https://periodicos.unifap.br/index.php/letras

Macapá, v. 6, n. I, Io semestre, 2016. 


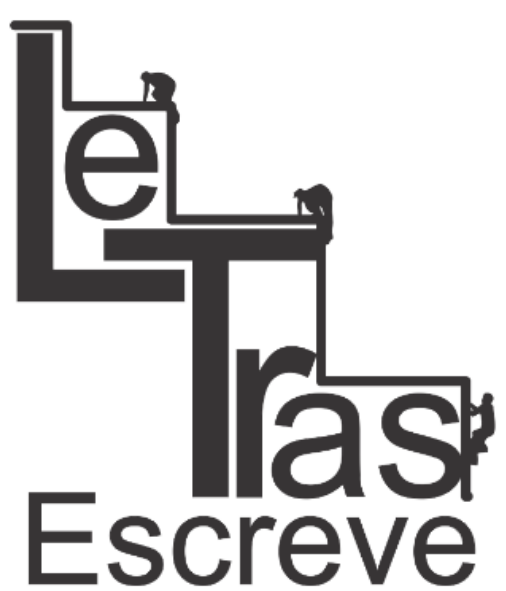

(ISSN 2238-8060)

da hipótese de que situações traumáticas, como a violência, podem - ainda - ser representadas por meio de um modus operandi realista, sem perderem sua qualificação artística e seu poder de crítica social.

O parâmetro estético realista considerado obsoleto pelos estudos de Ginzburg é aquele apresentado por lan Watt, em $A$ ascensão do romance. Segundo o crítico, o foco narrativo objetivo da tradição realista poderia conduzir a um distanciamento empedernido para com os fatos narrados, tornando-se pouco profícuo em temas de situações extremas. Além disso, o narrador centrado em um fundamento de objetividade não teria capacidade de explorar um campo semântico de crítica social. Para Ginzburg, a presença de narradores descentrados seria uma marca de significativa parcela da produção literária nacional nos últimos decênios:

A principal hipótese de reflexão consiste em que, na contemporaneidade, haveria uma presença recorrente de narradores descentrados. O centro, nesse caso, é entendido como um conjunto de campos dominantes na história social - a política conservadora, a cultura patriarcal, o autoritarismo de Estado, a repressão continuada, a defesa de ideologias voltadas para o machismo, o racismo, a pureza étnica, a heteronormatividade, a desigualdade econômica, entre outros. $O$ descentramento seria compreendido como um conjunto de forças voltadas contra a exclusão social, política e econômica. (GINZBURG, 2012, p. 201).

Nesse sentido, o pesquisador cita vários narradores díspares do padrão convencional, a exemplo do homossexual, em Triângulo em cravo e Flauta Doce, de Caio Fernando Abreu, do incestuoso, em Lavoura Arcaica, de Raduan Nassar, entre outros. A esse índice, queremos propor o acréscimo do narrador do conto Feliz ano novo, de Rubem Fonseca, um negro marginalizado e criminoso: descentrado, portanto. Todavia, argumentaremos que a emergência de narradores descentrados pode não ser condição suficiente para

https://periodicos.unifap.br/index.php/letras Macapá, v. 6, n. I, Io semestre, 2016. 


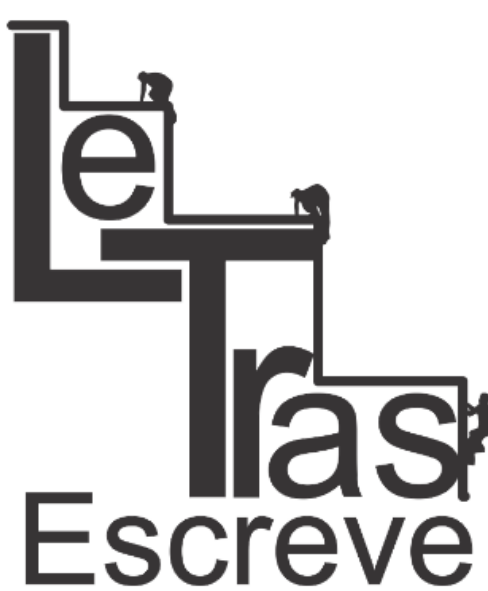

(ISSN 2238-8060)

uma recusa da estética realista. Então, a indagação que se impõe é: de que realismo estamos falando?

Evidentemente, advogar em defesa de um realismo nos mesmos moldes do analisado por lan Watt para a criação estética hodierna constituiria, no mínimo, uma anacronia. As técnicas de verossimilhança descritiva e da objetividade da narrativa do realismo tradicional não são tout court "copiadas" pelos escritores contemporâneos, mesmo porque o contexto atual é diverso daquele do nascimento do gênero romanesco ou do realismo histórico do século XIX. Não há razão para se comparar, gratuitamente, o realismo atual com o realismo do passado. O que precisamos salientar é - mesmo em obras analisadas nos competentes artigos de Ginzburg - a emergência de uma linguagem enxuta, direta, ríspida, vigorosa e enérgica na representação de temas caros a uma posição de crítica social. Assim, a partir da década de 1960, floresceu uma prosa caracterizada pela recriação artística da violência cotidiana dos grandes centros urbanos ${ }^{3}$, seguidamente sob a ótica de setores sociais periféricos. O novo realismo, inaugurado por Rubem Fonseca, é caracterizado "[...] pela vontade de relacionar a literatura e a arte com a realidade social e cultural da qual emerge, incorporando essa realidade esteticamente dentro da obra e situando a própria produção artística como força transformadora" (SCHOLLHAMMER, 2011, p. 54).

Desse modo, parece-nos que a técnica realista das narrativas de Rubem Fonseca, ao incorporarem como leitmotiv a violência urbana, por meio de uma forma marcada por um relato conciso da ação, de um léxico coloquial e direto, produz um efeito de choque, de perplexidade, quer pela brutalidade das cenas e palavras, quer pelo contraste entre essa brutalidade e as expressões jocosas, dialogando com a realidade concreta de maneira crítica. Em outras palavras, o escritor fluminense, em seu ato estético, opera com a

\footnotetext{
${ }^{3}$ Devemos recordar que tal estética realista foi intitulada de brutalismo, por Bosi (1975).
}

https://periodicos.unifap.br/index.php/letras Macapá, v. 6, n. I, Io semestre, 2016. 
realidade, na medida que "[...] transfere essa realidade conhecida e avaliada para um outro plano axiológico, submete-a a uma nova unidade, ordena-a de modo novo [...]" (BAKHTIN, 2010, p. 33), construindo uma posição axiológica de contestação à violência justamente pela forma em que se realiza. Podemos afirmar que a realidade extraestética da violência, atravessada por valorações que a minimizam, é refratada no universo ficcional, com o peso da banalização da violência expresso tanto no conteúdo, quanto na forma. Assim, cremos que a prosa de Rubem Fonseca efetua uma ação que vai de realibus ad realiora. Dialoguemos com o objeto de estudo.

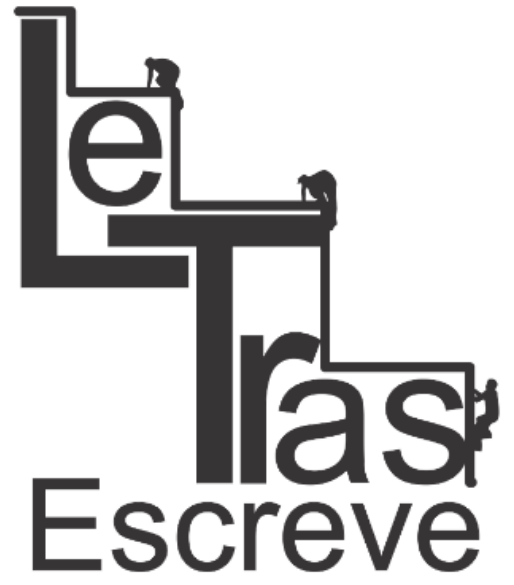

(ISSN 2238-8060)
Atirei bem no meio do peito dele, esvaziando os dois canos, aquele tremendo trovão. O impacto jogou o cara com força contra a parede. Ele foi escorregando lentamente e ficou sentado no chão. No peito dele tinha um buraco que dava para colocar um panetone. (FONSECA, 2005, p. 19).

O excerto narrativo, pertencente ao conto Feliz ano novo, de Rubem Fonseca, permite a percepção do uso de uma linguagem direta, articuladora de uma mimese ao estilo realista, sem experimentalismo formal. A cena, em sua forma "tradicional", não evidencia inovações estéticas como a fragmentação ou a descontinuidade.

Retornando à cena, ela expõe um assassinato violento por meio de um tom emotivo-volitivo de normalidade, como algo prosaico, lúdico inclusive, como a referência ao "panetone" em sugestão ao tamanho do buraco aberto no peito do assassinado pela descarga da arma. Através desse excerto, podemos compreender a estreita relação entre a forma e o conteúdo, articulando uma posição de crítica à violência, tão banalizada que não causa espanto ou perplexidade no interior do universo ficcional. Paralelamente, parece-nos, no entanto, que pode surtir um efeito de choque no leitor justamente pela forma com que é representada, ou seja, com um léxico cru, ríspido e direto. $\mathrm{E}$, pelo choque, potencializa um

https://periodicos.unifap.br/index.php/letras Macapá, v. 6, n. I, Io semestre, 2016. 


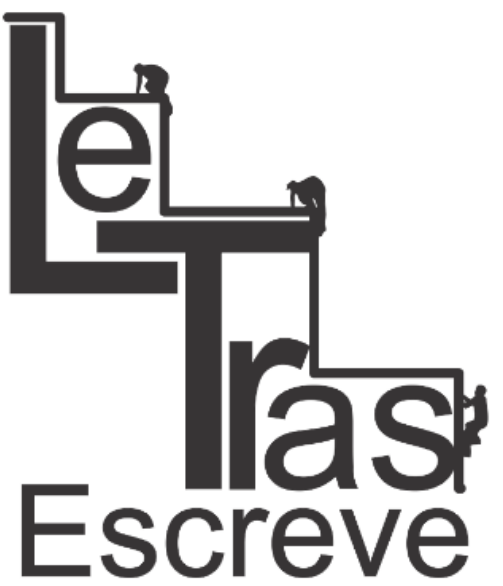

(ISSN 2238-8060) sentimento de repúdio à violência banal. Com esse entendimento, rechaçamos a priori qualquer possibilidade de compreensão do texto pelo viés de uma apologia da violência, antes exatamente o contrário.

A violência, sobremodo a urbana, de fato constitui o tema de Feliz ano novo e de Passeio noturno (partes 1 e 2), contos que integram a coletânea intitulada Feliz ano novo, de 1975 (censurada pelo governo militar), e que formam nosso objeto de análise. Um leitmotiv que instala, ao lado da organização formal de matiz realista, uma posição axiológica no mundo ficcional e, em diálogo com a realidade concreta, uma posição de contrariedade para com a violência, suas fontes e sua naturalização por meio da banalização.

Considerando-se como paradigma a relação entre a literatura e o contexto de produção, entendemos que o escritor de Feliz ano novo incorpora às narrativas, de maneira estetizada, elementos extraestéticos do mundo circundante, como a gratuidade da violência, e posiciona-se criticamente na escolha do tema e da forma de realizá-lo. Em acordo com o pensamento de Candido (2010), o externo se torna interno, passando a funcionar de maneira específica no interior da narrativa.

Assim, a violência tornada prosaica na sociedade é refletida e refratada no ato estético, permanecendo seu traço cotidiano, mas instalando uma posição axiológica de desacordo, sobremaneira na forma lexical escolhida para representar a mesma. Em outras palavras, as narrativas procuram chocar e instigar à reflexão precisamente através da forma com que apresentam o conteúdo, construindo então uma posição de contestação ao senso comum, e performativamente realizando o de realibus ad realiora, em contraponto aos experimentalismos estéticos de repercussão estéril. Evidentemente, o autor labora em sua criação artística com objetossigno que o circundam, como a violência gratuita, ou seja, com o meio ideológico, assim definido por Medviédev:

https://periodicos.unifap.br/index.php/letras Macapá, v. 6, n. I, Io semestre, 2016. 


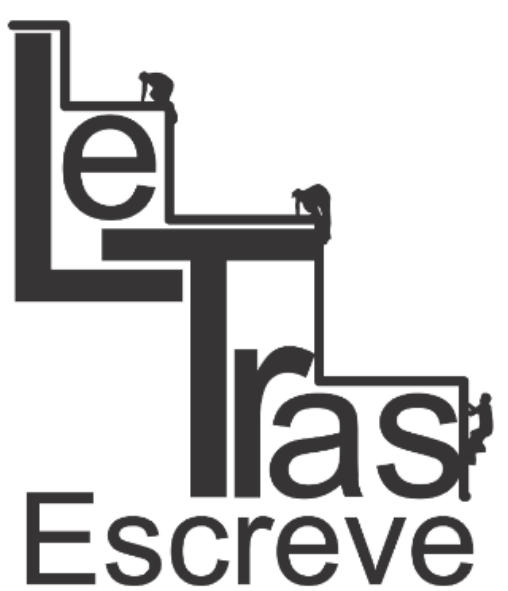

(ISSN 2238-8060)
O homem social está rodeado de fenômenos ideológicos, de "objetos-signo" dos mais diversos tipos e categorias: de palavras realizadas nas suas mais diversas formas, pronunciadas, escritas e outras; de afirmações científicas; de símbolos e crenças religiosas; de obras de arte, e assim por diante. Tudo isso em seu conjunto constitui o meio ideológico que envolve o homem por todos os lados em um círculo denso. Precisamente nesse meio vive e se desenvolve sua consciência. A consciência humana não toca a existência diretamente, mas através do mundo ideológico que a rodeia. (MEDVIÉDEV, 2012, p. 56, grifo do autor).

O meio ideológico no qual Rubem Fonseca está imerso ao criar Feliz ano novo e Passeio noturno (partes 1 e 2) é a Ditadura Civil-Militar (1964-1985), caracterizada pelo autoritarismo, pela violência e pela censura, orientados pela Doutrina de Segurança Nacional, a qual prevê o combate aos supostos subversivos como uma meta imprescindível, conforme podemos ler em Comblin (1978). De acordo com a Doutrina, todas as medidas arbitrárias eram necessárias para o combate ao perigo comunista, avalizando, então, sob a ótica governamental, a tortura e a censura, e criando especialmente após o Ato Institucional $n^{\circ} 5$, de 1968 - uma cultura do medo, segundo Alves (1985), na qual todos eram potenciais subversivos. Ao mesmo tempo, em sua diretriz econômica, a Doutrina previa o desenvolvimento do capitalismo associado e dependente do estrangeiro, aprofundando as desigualdades sociais, de acordo com Gaspari (2002). É precisamente esse meio ideológico que circundava o escritor, interagindo com ele; fazendo-o tomar uma específica posição perante o mesmo. Para corroborar o exposto, dialoguemos com o objeto.

Em Feliz ano novo, no Rio de Janeiro, três jovens de condição social marginalizada encontram-se no apartamento, bastante precário, do narrador-personagem, sem dinheiro, sem comida, sem água, consumindo entorpecentes ilícitos e vendo televisão na noite de 31 de dezembro. Decidem sair pela cidade e assaltar uma casa de gente rica em meio à comemoração do ano novo. Durante o assalto, matam quatro pessoas, defecam na cama e nos lençóis, 
comem a ceia, roubam joias e relógios e estupram uma mulher.

Retornam ao apartamento e celebram o ano novo. Observemos:

Acendemos uns baseados e ficamos vendo a novela. Merda. Mudamos de canal, prum bangue-bangue. Outra bosta.

As madames granfas tão todas de roupa nova, vão entrar o ano novo dançando com braços pro alto, já viu como as branquelas dançam? Levantam os braços pro alto, acho que é pra mostrar o sovaco, elas querem mesmo é mostrar a boceta mas não têm culhão e mostram o sovaco. Todas corneiam os maridos. Você sabia que a vida delas é dar a xoxota por aí?

Pena que não tão dando para gente, disse Pereba. Ele falava devagar, gozador, cansado, doente.

Pereba, você não tem dentes, é vesgo, preto e pobre, você acha que as madames vão dar pra você? Ô Pereba, o máximo que você pode fazer é tocar uma punheta. Fecha os olhos e manda brasa.

Eu queria ser rico, sair da merda em que estava metido! Tanta gente rica e eu fudido. (FONSECA, 2005, p. 14)

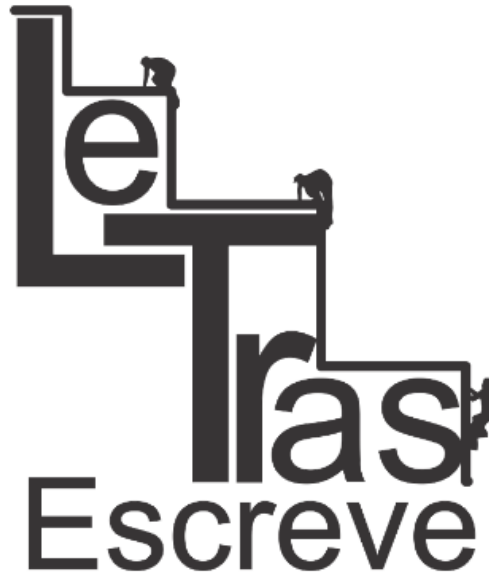

(ISSN 2238-8060)

O fragmento representa a miséria das personagens em franco contraste com a alta sociedade, a desigualdade social recrudescida pelo capitalismo - cruamente exposta. Além disso, percebemos que os protagonistas são negros pela maneira com que chamam as "madames" de "branquelas", além da identificação de Pereba como negro. A estreita relação entre a população negra e as péssimas condições de vida, expressa no texto literário, pode ser entendida como um reflexo e uma refração da realidade concreta brasileira, pois, historicamente, a miserabilidade assola com maior intensidade os negros em comparação com os brancos, conforme dados de pesquisas do Instituto Brasileiro de Geografia e Estatística (em 2011, por exemplo, 71\% das pessoas em condição de extrema pobreza se autodeclarou negra ou parda).

Ao lado da denúncia da miséria da população negra, na sequência da narrativa, erige-se o descortinamento da violência urbana. Vejamos a cena que ocorre durante o assalto de uma casa em que estavam 25 pessoas comemorando a passagem de ano, depois do primeiro homem ser morto com um tiro no peito:

https://periodicos.unifap.br/index.php/letras

Macapá, v. 6, n. I, Io semestre, 2016. 


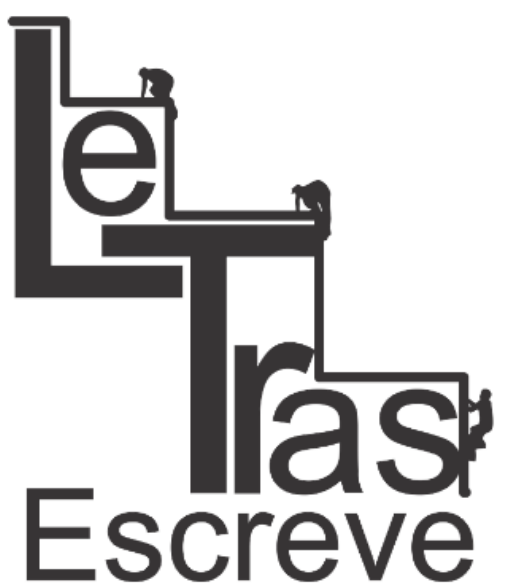

(ISSN 2238-8060)
Você aí, levante-se, disse Zequinha. O sacana tinha escolhido um cara magrinho, de cabelos compridos.

Por favor, o sujeito disse, bem baixinho.

Fica de costas para a parede, disse Zequinha.

Carreguei os dois canos da doze. Atira você, o coice dela machucou meu ombro. Apoia bem a culatra senão ela te quebra a clavícula.

Vê como esse vai grudar. Zequinha atirou. O cara voou, os pés saíram do chão, foi bonito, como se ele tivesse dado um salto para trás. Bateu com estrondo na porta e ficou ali grudado. Foi pouco tempo, mas o corpo do cara ficou preso pelo chumbo grosso na madeira. (FONSECA, 2005, p. 20)

A "brincadeira" entre os assaltantes consistia em saber se um homem ficaria pregado na parede com a descarga de uma arma de calibre 12. Escolhem, aleatoriamente, sem nenhuma autoreprovação ética, um rapaz e o assassinam, inclusive comentando o narradorpersonagem que foi "lindo". Efetivamente, a narrativa choca pela simplicidade lexical ostensiva com que representa o assassinato, a violência gratuita, banal, e a completa desumanização dos assaltantes. Em nosso entendimento, não efetua uma apologia à violência, como já afirmamos anteriormente, mas instiga à reflexão sobre a banalização da mesma, a desumanização dos indivíduos. Além disso, se cotejarmos os dois excertos apresentados anteriormente, podemos admitir uma clave de explicação em que a violência cometida pelo narrador-personagem e seus amigos, embora naturalizada em sua banalidade, aponta para um instigamento da reflexão sobre os motivos que podem ter levado as personagens aos atos violentos: a desigualdade social, embora não de forma determinista e generalizante. $E$, na hipótese de tal compreensão ser adequada, percebermos para além de uma irracional e gratuita violência das personagens pobres, uma outra violência, que atua sobre os mesmos, ou seja, a violência da estrutura econômica capitalista e seus abismos sociais.

Neste ponto de nosso estudo, faz-se necessária uma definição de violência (ou violências, se considerarmos a questão taxonômica):

https://periodicos.unifap.br/index.php/letras

Macapá, v. 6, n. I, Io semestre, 2016. 


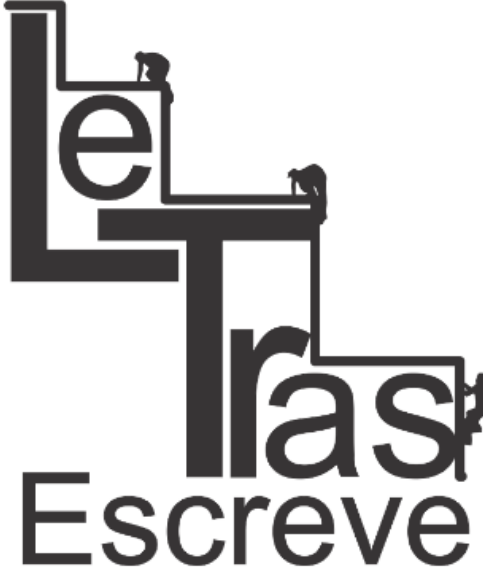

(ISSN 2238-8060)
[...] há violência quando, numa situação de interação, um ou vários atores agem de maneira direta ou indireta, maciça ou esparsa, acusando danos a uma ou várias pessoas em graus variáveis, seja em sua integridade física, seja em sua integridade moral, em suas posses, ou em suas participações simbólicas e culturais. (MICHAUD, 1989, p. 10).

Desse modo, o narrador-personagem e seus cúmplices são os atores de diferentes violências no conto: causam danos à integridade moral, psicológica e física das pessoas que assaltam, estupram e matam. Por outro lado, se considerarmos a tipologia da violência proposta por Santos (1993), os atores da violência explícita na narrativa são alvo de uma violência implícita, a do sistema do capital, da estrutura econômica. Não estamos afirmando, evidentemente, que a causa da violência do narrador-personagem e seus amigos seja a miséria, mas que a mesma pode ser uma influência, jamais determinista, no entanto.

Panorama diverso ocorre em Passeio noturno (partes 1 e 2). Considerando-se a plausibilidade de lermos os dois contos em uma relação de continuidade, como sugere o elemento paratextual do título, temos um homem de condição social favorecida, um empresário casado e com filhos, ou seja, uma típica família no sentido convencional do termo (um narrador centrado, se considerarmos a classificação de Ginzburg), que possui o costume de sair à noite dirigindo seu automóvel - sem direção, sem escolher homem ou mulher - até encontrar alguém e assassiná-lo por meio do atropelamento. Como em Feliz ano novo, a linguagem empregada nas narrativas é de cor realista, objetiva, simples e linear, sem qualquer rebuscamento ou experimentalismo formal. Observemos a cena do atropelamento da primeira parte de Passeio noturno:

Apaguei as luzes do carro e acelerei. Ela só percebeu que eu ia para cima dela quando ouviu o som da borracha dos pneus batendo no meio-fio. Peguei a mulher acima dos joelhos, bem no meio das duas pernas, um pouco mais sobre a esquerda, um golpe perfeito, ouvi o barulho do impacto partindo os dois

https://periodicos.unifap.br/index.php/letras

Macapá, v. 6, n. I, Io semestre, 2016. 


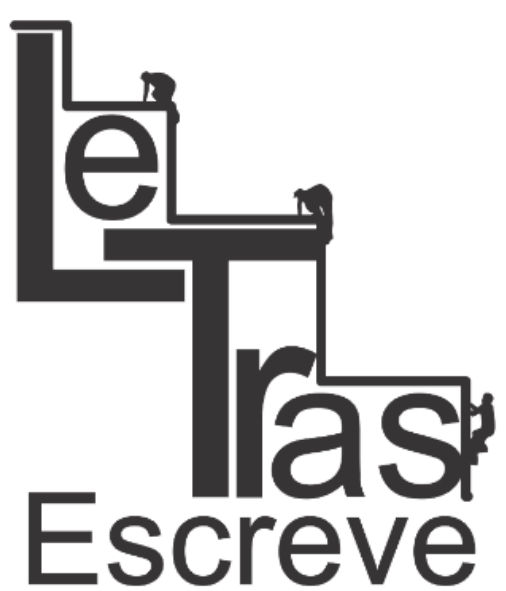

(ISSN 2238-8060) ossões, dei uma guinada rápida para a esquerda, passei como um foguete rente a uma das árvores e deslizei com os pneus cantando, de volta para o asfalto. Motor bom, o meu, ia de zero a cem quilômetros em nove segundos. Ainda deu para ver que o corpo todo desengonçado da mulher havia ido parar, colorido de sangue, em cima de um muro, desses baixinhos de subúrbio. (FONSECA, 2005, p. 62).

O narrador-personagem assassina uma mulher através do atropelamento, em uma cena descrita com absoluta coerência lógica no campo da sintaxe. No campo hermenêutico, a fala do assassino revela o descaso para com a alteridade, expondo palavras que sugerem tratar-se de uma personalidade com algum grau patológico, como os elogios à própria ação: "passei como um foguete", "Motor bom, o meu, ia de zero a cem quilômetros em nove segundos", "colorido de sangue", ou seja, expressões inadequadas para uma psique equilibrada em tal situação.

No segundo atropelamento, em Passeio noturno (parte 2), o narrador-personagem é abordado por uma mulher no trânsito, a qual Ihe joga um bilhete contendo seu nome - Ângela - e o número de seu telefone. O homem, que tudo nos leva a considerar tratar-se do mesmo de Passeio noturno (parte 1), - note-se, au passant, que o explicit textual e narrativo é idêntico na Parte 1 e na Parte 2, afinal ambos os contos terminam com o homem dando boa noite à esposa e dizendo que vai dormir, pois "Amanhã vou ter um dia terrível na companhia" (FONSECA, 2005, p. 63 e 71) - liga para Ângela e marca um encontro. Segue-se um diálogo, no qual o narradorpersonagem não demonstra interesse, tampouco sensibilidade à fala da mulher, e, logo depois, a assassina por meio de um atropelamento:

Bati em Ângela com o lado esquerdo do pára-lama, jogando seu corpo um pouco adiante, e passei, primeiro com a roda da frente - e senti o som surdo da frágil estrutura do corpo se esmigalhando - e logo atropelei com a roda traseira, um golpe de misericórdia, pois ela já estava liquidada, apenas talvez ainda sentisse um distante resto de dor e perplexidade. (FONSECA, 2005, p. 71). 


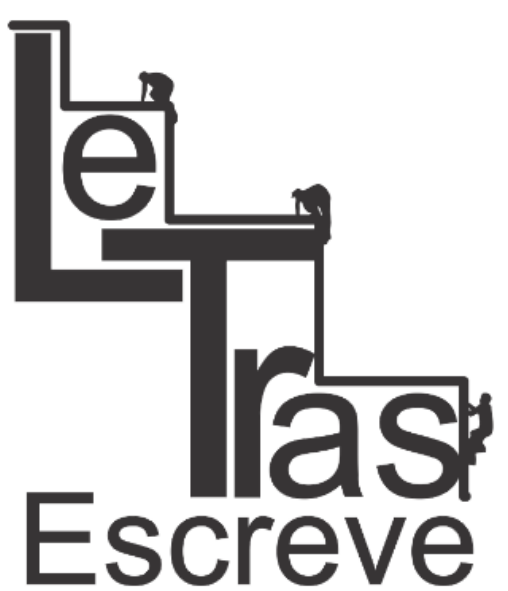

(ISSN 2238-8060)

Novamente, uma estrutura frasal coerente para descrever um ato atroz. A violência cometida pelo homem é, evidentemente, de tipo físico, o assassinato, assim como também ocorre em Feliz ano novo. Porém, a violência em Passeio noturno (partes 1 e 2) não apresenta como possível causa a deplorável condição social, qual seja, a miséria das personagens de função ativa em Feliz ano novo, mas, sim, uma possível patologia psicológica. Segundo Freud (2011), os instintos humanos não são todos da mesma espécie, coexistindo Eros e Tânatos, este último entendido como um instinto de morte que "[...] se volta contra o mundo externo e depois vem à luz como instinto de agressão e destruição" (FREUD, 2011, p. 64), culminando na agressão máxima da eliminação física do outro.

Além disso, o narrador-personagem que comete os atropelamentos apresenta características que o aproximam da patologia psíquica denominada de psicopatia, como a indiferença aos sentimentos dos outros, a propensão à violência, a ausência do sentimento de culpa ou de remorso, a aparente normalidade de conduta, entre outros, segundo podemos ler em Calheiros (2013). Ratifica essa identificação da causa da violência em uma personalidade psicopata o fato de o narrador-personagem estar inserido na sociedade, sendo que a quebra com a ordem se dá pelo ato de violência, sobre o qual, no entanto, ele toma todos os cuidados para que não seja percebido pelas autoridades policiais, e não se culpa pela ação. Dessa forma, conforme Calheiros (2013, p. 11), "[...] em todos os psicopatas, independentemente do tipo de comportamento, subsiste sempre a ausência de sentimento de culpa”.

As narrativas, portanto, apresentam situações extremas, nas quais os narradores são protagonistas de atos violentos narrados com o emprego de uma linguagem que obedece à mimese realista, objetiva, sem rebuscamentos ou experimentalismos de forma. Com isso, o autor efetua, no ato estético, um reflexo e uma refração do meio ideológico que o cerca, sobremodo a banalização da violência, 


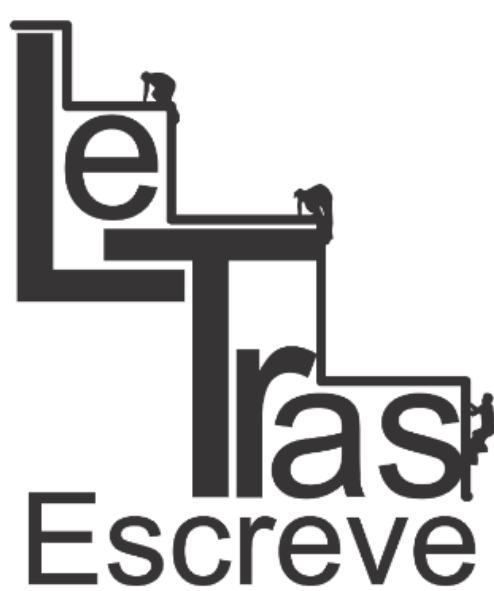

(ISSN 2238-8060)

chocando o leitor exatamente pela linguagem brusca, "feroz" empregada - destituída de pirotecnias formais ou de pontuação - e permitindo o entrever de uma possível causa para diferentes tipos de violência: em Feliz ano novo, a miséria e as terríveis desigualdades sociais; em Passeio noturno (partes 1 e 2), um transtorno psicopatológico, que aproximamos à psicopatia. E, ao cotejarmos as causas das violências nas narrativas, podemos perceber uma crítica social de segundo grau: a de que a violência está em todos os segmentos sociais e que, no senso comum e ordinariamente, a violência cometida pelos mais desfavorecidos economicamente é sempre considerada bestial, irracional e indefensável, ao passo que aquela efetuada pelos privilegiados socialmente é explicada como patologia, dirimindo então o dolo do agente. Efetivamente, a violência constitui o leitmotiv dos contos analisados, mas com uma função axiológica de contestação à sua banalização e à generalização da explicação das suas causas, constituindo-se, então, em uma forte crítica social, o que torna as narrativas impregnadas da contemporaneidade na acepção de Agamben (2009), ainda mais contundente pelo uso de uma estrutura narrativa impregnada de um real mais real.

\section{Referências bibliográficas}

AGAMBEN, G. O que é o contemporâneo e outros ensaios. Tradução Vinicius Honesko. Chapecó / SC: Argos, 2009.

ALVES, Maria Helena Moreira. Estado e oposição no Brasil (19641984). Tradução de Clóvis Marques. 3.ed. Rio de Janeiro: Vozes, 1985.

BAKHTIN, M. Questões de literatura e de estética: a teoria do romance. Tradução de Aurora Bernardini et al. São Paulo: Hucitec, 2010.

https://periodicos.unifap.br/index.php/letras Macapá, v. 6, n. I, Io semestre, 2016. 


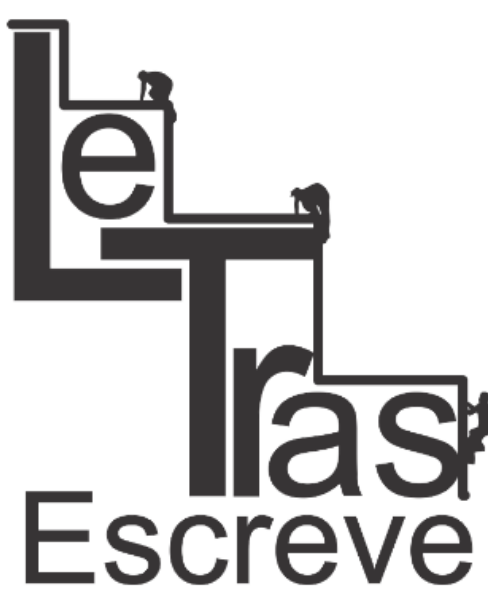

(ISSN 2238-8060)

BAKHTIN, M; VOLOCHÍNOV. Marxismo e filosofia da linguagem: problemas fundamentais do método sociológico da linguagem. Tradução de Michel Laud et al. 13.ed. São Paulo: Hucitec, 2012. BOSI, Alfredo. O conto brasileiro contemporâneo. São Paulo: Cultrix, 1975.

CALHEIROS, Mafalda. Psicopatia e perversão: características comuns e diferenciais, processo de passagem ao ato e perfil criminal. Dissertação (Mestrado em Psicocriminologia). Instituto Universitário: Ciências psicológicas, sociais e da vida. Lisboa / Portugal, 2013.

CANDIDO, Antonio. Literatura e Sociedade: Estudos de Teoria e História Literária. 11.ed. Rio de Janeiro: Ouro sobre Azul, 2010.

COMBLIN, J. A Ideologia da Segurança Nacional: O Poder Militar na América Latina. Tradução de Veiga Filho. 2.ed. Rio de Janeiro: Civilização Brasileira, 1978.

FREUD, S. O mal-estar na civilização. Tradução de Paulo César de Souza. São Paulo: Penguin / Cia das Letras, 2011.

FONSECA, Rubem. Feliz ano novo. Rio de Janeiro: Cia das Letras, 2005.

GASPARI, Élio. A Ditadura Escancarada. São Paulo: Cia das Letras, 2002.

GINZBURG, Jaime. Escritas da Tortura. In: Diálogos Latinoamericanos. $n^{\circ} 003$. Universidade de Aarhus. 2001. p.131-146.

. O narrador na literatura brasileira contemporânea. In: Quaderni di letterature iberiche e iberoamericane. Vol. 2. 2012. p. 199-221.

MEDVIÉDEV, P. O método formal nos estudos literários: introdução crítica a uma poética sociológica. Tradução de Sheila Camargo e Ekaterina Américo. São Paulo: Contexto, 2012.

MICHAUD, Y. A violência. São Paulo: Ática, 1989.

SANTOS, José Vicente Tavares dos. A cidadania dilacerada. In: Revista Crítica de Ciências Sociais. N 37, junho / 1993, p. 131-148, Porto Alegre, UFRGS, 1993.

https://periodicos.unifap.br/index.php/letras Macapá, v. 6, n. I, Io semestre, 2016. 
SCHOLLHAMER, Karl E. Ficção brasileira contemporânea. Rio de Janeiro: Civilização Brasileira, 2011.

Recebido em 25/07/2016. Aprovado em 07/08/2016.

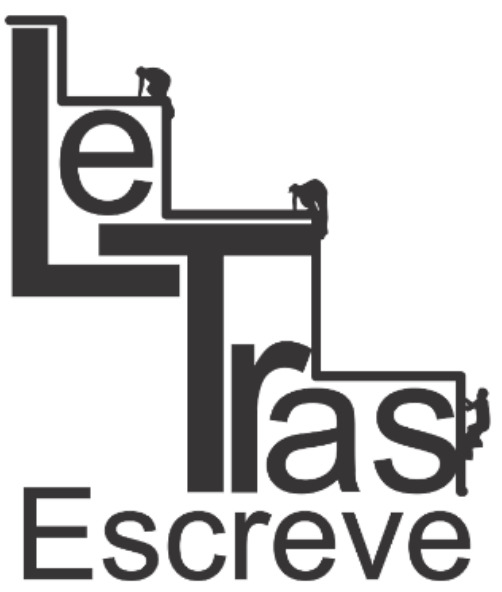

(ISSN 2238-8060) 